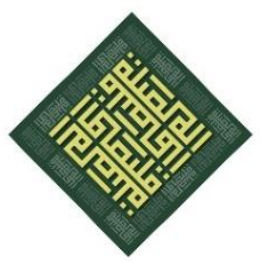

El-Mashlahah

Volume 11 No. 2, December 2021

ISSN: E-ISSN: 2622-8645; P-ISSN: 2089-1970

DOI: $10.23971 /$ elma.v11i2.2825

\title{
FORMALIZATION OF ISLAMIC LAW IN INDONESIA IN THE FRAMEWORK OF SOCIAL ENGINEERING THEORY BY ROSCOE POUND
}

\author{
Zainal Muttaqin \\ Faculty of Sharia, UIN Antasari Banjarmasin, Indonesia \\ zainalmuttaqin@uin-antasari.ac.id
}

Received: 26-04-2021; Accepted:20-12-2021; Published: 23-12-2021;

\begin{abstract}
Law has a very important role in people's lives. And, the law is assumed to have multifunctionality for the goodness of the community itself to achieve justice, legal certainty, orderly, advantages, and others. However, along with changes of time, the changes occur in people's lives that lead the law, as a binding norm, also changes following the harmony with the good of the community itself. In Indonesia, Islamic law as one of the sources of law and a living law has a role in social engineering efforts towards a better life for Indonesian people. Therefore, the problem is, how Islamic law can be a means for social engineering? The answer is, Islamic law can be a means of social engineering by becoming a positive law into legislation. Here, the formalization of Islamic law is urgent. But, the formalization must manifest in form of transformation and internalization of the values contained in Islamic law into the national law. Islamic law is not a static norm but a norm that can perform the dynamizing thought and engineering people's political behavior in realizing their ideals
\end{abstract}

Keywords: Formalization of Islamic Law; Social Engineering Theory; and Roscoe Pound;

\footnotetext{
ABSTRAK

Hukum mempunyai peranan yang sangat penting dalam kehidupan masyarakat, bahkan hukum dianggap mempunyai multifungsi untuk kebaikan masyarakat itu sendiri demi tercapainya keadilan, kepastian hukum, ketertiban, kemanfaatan dan lain-lain. Namun seiring dengan terjadinya perubahan waktu, maka terjadi pula perubahan dari kehidupan masyarakat sehingga hukum sebagai sebuah norma yang mengikat juga mengalami perubahan yang selaras dengan kebaikan masyarakat itu sendiri. Hukum Islam sebagai salah satu sumber hukum dan hukum yang hidup di tengah masyarakat (living law) Indonesia mempunyai peran yang tidak dapat diabaikan dalam upaya rekayasa sosial (social engineering) ke arah kehidupan masyarakat Indonesia yang lebih baik. Oleh karena itu, problematikanya adalah bagaimana hukum Islam bisa menjadi sarana untuk rekayasa tersebut. Hukum Islam bisa menjadi sarana rekayasa sosial dengan menjadi hukum yang positif dalam bentuk perundang-undangan. Dalam hal ini formalisasi hukum Islam tidak akan terelakkan. Namun formalisasi tersebut harus dalam bentuk tranformasi dan internalisasi nilai-nilai yang terdapat dalam hukum Islam ke dalam bentuk hukum nasional. Hukum Islam bukannya sebagai sebuah norma statis namun
} 
harus dipahami dalam bentuk norma yang mampu untuk mendinamisasi pemikiran dan merekayasa perilaku politik masyarakat dalam mewujudkan cita-citanya.

Kata Kunci: Formalisasi Hukum Islam; Teori Rekaya Sosial; dan Roscoe Pound;

\section{Introduction}

Orderly and peaceful community life can occur when everyone obeys and consider the law, which defines as a set of norms that regulate people's behavior. Those norms are created in a certain way and enforced by the government. ${ }^{1}$ In efforts to law enforcement, the role of the state is very important, especially in the context of state politics. This reason has implications for the style and form of law enforcement. ${ }^{2}$ In the relation between law and politics, Achmad Ali notes that they have a close relationship. For example, written law is a universal political tool, and it shows more role when is used as a tool or means for social change. ${ }^{3}$

One of the legal theories states that the law has a very important role in people's lives. And, the law is assumed to have multifunctionality for the goodness of the community itself to achieve justice, legal certainty, orderly, advantages, and others. These are the national political ideals of a nation and state. But, it must be admitted that the relationship between law and politics, the state authorities sometimes use the law as a tool to pressure the public, aiming they can follow the interests of the state authorities. $^{4}$

Sociology science explains that law is seen as having two major functions. The functions are social control and social engineering. The law as a means for social control function aims to provide and keep order and justice conditions in the middle of people's lives. Then, the law may manifest into punishment, compensation, therapy, and even conciliation.

Meanwhile, in the context of social engineering, the law is seen as a means to make social change. Social change is a need due to the changes in culture, social, and community behavior as the impact of advances in knowledge, technology, and

\footnotetext{
1 Ashadi L Diab, "Peranan Hukum Sebagai Social Control, Social Engineering Dan Social Welfare," Al-'Adl 7, no. 2 (2014): 53-66, https://ejournal.iainkendari.ac.id/al-adl/article/view/219.

2 Ahmad Ali, Menguak Tabir Hukum (Suatu Kajian Sosiologis Dan Filosofis) (Jakarta: Toko Gunung Agung, 2002).

${ }^{3}$ Ali.

${ }^{4}$ Nazaruddin Lathif, "Teori Hukum Sebagai Sarana Alat Untuk Memperbaharui Atau Merekayasa Masyarakat," Palar | Pakuan Law Review 3, no. 1 (2017): 73-94, https://doi.org/10.33751/palar.v3i1.402. 
information. These changes can occur in values, rules, behavior, organization, the structure of social institutions, social stratification, social interaction, power, and others. ${ }^{5}$ Therefore, with the cultural and social advancement of society today, the law presents its role to change the people's thinking patterns from traditional into rational or modern.

Islam that is both religion and teachings also has a set of rules, norms, and laws aiming to regulate the behavior of its follower. Islam also does not deny the social changes that occur in the lives of people. In Islamic law, legal changes are a must, especially related to social relations (mu'amalah). The changes usually occur due to the demands of social, cultural, and times. There is a rule of law that is used to legitimize the legal change, called tagayyur al-ahkam bitagayyur azminah wa amkinah. The problem is, how Islamic law become a means of social engineering in the form of formalizing Islamic law in Indonesia.

Several studies have been conducted. Rahmatunnair stated that the formalization of Islamic law in the national legal system is the right choice, neither the symbolic formalization of Islamic law nor establishing an Indonesian Islamic state. Because she argued, such kind of effort will only distort the Indonesian nation and Muslims themselves. ${ }^{6}$ Supported by Tomi Agustian that Islamic law has been applied substantively referring the history of the application the Islamic law and legal political policies in Indonesia. ${ }^{7}$

Besides that, Kurniawan described that the founding father of Indonesia designed this country was not for a certain religious state, but a state based on the psychological similarity of suffering due to colonialism. If Muslims insist on implementing Islamic law formally and comprehensively, it will become backfire for Muslims themselves when, after it is proclaimed, the community does not feel a justice and prosperous situation. $^{8}$ Also, Muhammad Ainun Najib stated that there was a need for a negotiated

\footnotetext{
5 Fatimah Halim, "Hukum Dan Perubahan Sosial," Al-Daulah: Jurnal Hukum Pidana \& $\begin{array}{llllll}\text { Ketatanegaraan } & 4, & \text { no. } & 1 & \text { (2015): } & \text { 107-15, }\end{array}$ alauddin.ac.id/index.php/al_daulah/article/view/1492.

${ }^{6}$ Rahmatunnair Rahmatunnair, "Paradigma Formalisasi Hukum Islam Di Indonesia," AHKAM : Jurnal Ilmu Syariah 12, no. 1 (2012): 99-108, https://doi.org/10.15408/ajis.v12i1.984.

${ }^{7}$ Tomi Agustian, "Formalisasi Hukum Islam Kedalam Tata Hukum Indonesia," EL-Ghiroh 16, no. 01 (2019): 15-36, https://doi.org/10.37092/el-ghiroh.v16i01.72.

${ }^{8}$ Kurniawan, "Dinamika Formalisasi Syariat Islam Di Indonesia," Kanun: Jurnal Ilmu Hukum 14, no. 3 (2017): 423-47, https://doi.org/10.24815/kanun.v14i3.6223.
} 
agreement among the religious-political elites of this country on how the state and religion should relate appropriately with clear boundaries. ${ }^{9}$

These studies tried to find a common ground on how to formalize Islamic law in Indonesia. And, the problems of the efforts need to be viewed from the framework of Roscoe Pound's social engineering theory. The efforts need to conduct to find out the contribution of Islamic law as a means of better social engineering among Indonesian society.

\section{Method}

The article tried to describe how Islamic law can be a means of social engineering, especially its position as a source of law in Indonesia. For this reason, the article used a qualitative descriptive research method with a literature study approach. In legal research, it is called normative legal research. ${ }^{10}$ The data were obtained through a searching process, then filtered and analyzed to produce a descriptive series to be presented in this article. The data sources obtained from reference materials, including books, titles, and others sources that have been through the process of review following the focus of the discussion in this article.

\section{Findings and Discussion}

\section{Application of Law as A Tool of Social Engineering Rescoe Pound}

In legal science literature, the concept of Law as a Tool of Social Engineering was first stated by Roscoe Pound, an American legal expert of the Sociological Jurisprudence. Sociological Jurisprudence is a school of legal philosophy developed by Eugen Erlich in Europe, ${ }^{11}$ and by Roscoe Pound in America. ${ }^{12}$ This school emphasizes the law that is seen not only on normative but also both normative and sociological phenomena at the same time. According to experts, this approach is a middle ground between two approaches, historical and positivism. The historical approach of thought

${ }^{9}$ Muhammad Ainun Najib, "Politik Hukum Formalisasi Syariat Islam Di Indonesia," IN RIGHT: Jurnal Agama Dan Hak Azazi Manusia 6, no. 2 (2017): 156-74, http://ejournal.uinsuka.ac.id/syariah/inright/article/view/1449.

${ }^{10}$ Sabarudin Ahmad, Novita Anggraeni, and Andrian Kukuh Pambudi, “A. Djazuli's Thinking Regarding Hifzu Al-Ummah: Dismissing the Entangled Bureaucracy to Commemorate the Era of Society 5.0," Journal de Jure 12, no. 1 (2020): 86-101, https://doi.org/10.18860/j-fsh.v12i1.8700.

${ }^{11}$ Lili Rasyidi, Filsafat Hukum (Bandung: Remaja Rosdakarya, 1988).

${ }^{12}$ Lili Rasyidi and Rasyidi Ira, Dasar-Dasar Filsafat Hukum (Bandung: Citra Aditya, 1990). 
views the law as sociological, and the positivism approach views the law as legal only. 13

Legal experts generally distinguish between Sociological jurisprudence and the sociology of law, although they both study law about society. In the scientific family, Sociological Jurisprudence is a branch of the philosophy of law, while the sociology of law is a branch of sociology. ${ }^{14}$ In terms of the object of study, they are also different. Sociological Jurisprudence uses a legal approach to society while the sociology of law is from society to law. ${ }^{15}$ Substantially, they have significant differences. If sociological jurisprudence focuses on law and views society about law, the sociology of law seeks to create a science of social life as a whole and its discussion covers the largest part of both sociology in general and political science. The emphasis of the investigation is on society and law as a manifestation. ${ }^{16}$

Discussing Rescoue Pound with the concept of law as a tool of social engineering means discussing the context of the legal function in society. As a follower of sociological jurisprudence, according to Rescoue Pound, the law must be viewed in terms of its function, which has function as a tool to manipulate (change) society. As a tool of social engineering, the function of law is not only to reach and keep longer the power but also plays as a tool to make changes in the middle of society. ${ }^{17}$ The goal is, to aim society to the expected goal. Furthermore, the law may use as a means to eliminate various bad habits of society, to become better habits. ${ }^{18}$

${ }^{13}$ Rasyidi and Ira. In the historical approach, the law grows and develops together with the community. Then, the law is not created by the authorities, but grows and develops following the development of society. In other words, the law is a product of society. Therefore, the view of this school of history is called sociological. In contrast, with a positivistic approach, the law is the sole command of the government. On the one hand, it makes the role of the government in the creation of law is very dominant. Moreover, it can be argued that in legal positivism, the development of law is in the hands of the government. Thus, if the law is merely an order from the government, this can lead to the direction and development of the law for the future which can be planned according to the needs of the government. In such a legal understanding, it can be understood that the element of legal certainty is the most prominent in legal positivism. Hotma P Sibuea and Waty Suwarty Haryono, "Pengaruh Mazhab Hukum Sosiological Jurisprudence Terhadap Perkembangan Pembangunan Hukum Di Indonesia Pada Masa Orde Baru," Jurnal Filsafat Hukum 1, no. 1 (2015): 103-11, http://journal.uta45jakarta.ac.id/index.php/JFH/article/view/1480.

${ }^{14}$ Rasyidi and Ira, Dasar-Dasar Filsafat Hukum.

${ }^{15}$ Rasyidi, Filsafat Hukum.

16 Dardi Darmodiharjo, Pokok-Pokok Filsafat Hukum: Apa Dan Bagaimana Filsafat Hukum Indonesia (Jakarta: Gramedia Pustaka Utama, 1996).

${ }^{17}$ Rasyidi and Ira, Dasar-Dasar Filsafat Hukum.

${ }^{18}$ Satjipto Raharjo, Ilmu Hukum (Bandung: Alumni, 1986). 
Related to this function, several types of interests must be protected by the law. First, public interest. It includes the interests of the state as a legal entity and guardian of the public interest. Second, the Social Interest. It includes the interests of peace and order, protection of social institutions, prevention of moral decline, prevention of violations of rights, and social welfare. Third, private interests. It includes individual interests, family interests, and property rights. ${ }^{19}$

According to A.P, Edi Atmaja, the word "tool" in the concept is not interpreted literally. But, it is interpreted as a means because the law is closely related to community factors, including beliefs, faith, and culture. The notion of 'tool' with a tool will make a rigid legal definition, thus ignoring its sociological aspects. There are proposed assumptions associated with this definition. First, the law contains doctrinal sources, such as values and principles, so that it provides content and substance in the development of law. Second, the law will always be dynamic, and will naturally develop along with the development of society. Third, the developments of legal will run regularly in a system to deal with human needs. Fourth, the function of the law is to regulate and keep the process of legal development can run freely (freedom). ${ }^{20}$ Thus, it concluded that the law in Rescoe Pound's view can be used as a means to make changes in the society so that arises a rule to change a negative habit into a positive habit, as a response to social and cultural changes of the community itself.

In Roscoue's view, the law is used as a tool to make changes in society that must occur in an orderly and planned. In this theory by Rescoue Pound, the dominant role of the state cannot be avoided. However, in this context, Pound's rescoue lives in an American country that adheres to a common law legal system, in which the making of laws is not in the hands of the legislature (law-making institutions) different from countries that follow the civil law legal system. In the common law system, the establishing law is in the hands of the judges, which are legally written in a judicial

${ }^{19}$ Johannes Ibrahim Kosasih and Yohanes Hermanto Sirait, "Konsepsi Law As A Tool Of Social Engineering Sebagai Upaya Manajemen Hukum Dalam Menciptakan Kepastian Hukum," in Konferensi Nasional Optimalisasi COmminity Well-Being Dalam Perspektif Multidisipliner (Bandung: Fakultas Psikologi Universitas Kristen Maranatha, 2015), 45-46.

${ }^{20}$ A.P. Edi Atmajaya, "Hukum Sebagai Sarana Rekayasa Sosial,” Opini Radar Lampung, 2012, https://issuu.com/ayep2/docs/300512/6. 
decision, which is the Supreme Court. ${ }^{21}$ Thus, the theory is relevant when applied in a state that adheres to the common law legal system. But, it might not be relevant to be applied to a civil law state legal system, such as Indonesia.

Mochhtar Kusumaatmaja in Soetandyo realized this problem when he introduced the sociological jurisprudence theory with the concept of Rescoue Pound, and applied the theory in Indonesia with the emergence of the theory of development law. In this theory, the law is not only played as a tool, but also a means of community renewal. In an article, Mochtar Kusumaatmaja once stated, that maximizing the law as a means of community renewal to reach government policies to develop the country is assumed to be more urgent than developed countries with already have a legal system that works to accommodate the changes occurring in the middle of society. While developing countries do not have such a legal system. ${ }^{22}$ Also, Mokhtar Kusumaatnaja stated that national development is intended to develop all aspects of people's lives. Community development can be characterized by the changes that occur. And, the role of law during development is, to assure that the changes occur orderly and regularly. ${ }^{23}$

Then, the problem is, how the concept of law as a tool of social engineering, which is practiced with the common law legal system, to be applied in countries with having a different legal system. For this reason, Mokhtar Kusumaatmaja explained in his statements. He stated that DPR (The House of Representatives of the Republic of Indonesia), as the people's representative in the process of forming laws following Article 11 of the Constitution, is the institution that can express legal awareness that lives in society. ${ }^{24} \mathrm{He}$ further stated that, besides the people's representative institutions, public legal awareness may arise through legal research conducted by educational and research institutions, as well as individuals. The role of the judiciary (judges), according to Mochtar Kusumaatmaja, also plays a role in the formulation of laws. He stated that jurisprudence is an important source of legal identification in society, added by the

21 Sibuea and Haryono, "Pengaruh Mazhab Hukum Sosiological Jurisprudence Terhadap Perkembangan Pembangunan Hukum Di Indonesia Pada Masa Orde Baru."

${ }^{22}$ Soetandyo Wigisoebroto, Dari Hukum Kolonial Ke Hukum Nasional: Dinamika Sosial Politik Dan Perkembangan Hukum Di Indonesia (Jakarta: Rajawali Press, 1994). 2002).

${ }^{23}$ Mochtar Kusumaatmadja, Konsep-Konsep Hukum Dalam Pembangunan (Bandung: Alumni,

${ }^{24}$ Kusumaatmadja. 
opinions of legal experts and scholars, especially those who are prominent in a particular branch of law science. ${ }^{25}$

There are two reasons, Hotma P Sibuea argued why DPR is the most appropriate state institution to grow up the legal awareness or values that live in society. First, the DPR is a state institution whose members are people's representatives who are elected in a general election. Therefore, a people's representative who sits in the DPR must know exactly the aspirations and interests of the constituents who choose them. Here, hypothetically, a member of DPR is expected to know and be sensitive to the people's aspirations. Second, according to the Indonesian constitutional system, the DPR constitutionally is a state institution authorized to make laws. ${ }^{26}$

Thus, in practice, the legal reform process in Indonesia is dominated by legislation. This fact shows, that in Indonesia, the effort to implement social reform with the law as a tool is a manifestation of legal positivism which emphasizes the reform through the law (written law).

In its development, Mochtar Kusumaatmaja with the theory of development law is assumed as failed in the efforts towards the idealization of a prosperous Indonesian state by using law as a means of social reconstruction. The fail is because the law formed by the DPR is not a law that contains elements of certainty and justice, as well as conceptualized by the sociological jurisprudence school. At that time, the law that was formed by the DPR more emphasized the element of certainty, while the aspect of justice was not always manifested proportionally (balanced). In a theory of legal function, the law formed by DPR during the New Order era emphasized its instrumental function than its expression function. The reason, the law during the New Order period served more as a tool to realize the programs determined by the authorities rather than realizing the aspirations and interests of the people. The program that has been determined by the government is like an employer who must be served and served by the law well, even though the interests of the people are not served and neglected. Moreover, the political and economic position of the lower-class of society is very weak

\footnotetext{
${ }^{25}$ Kusumaatmadja.

26 Sibuea and Haryono, "Pengaruh Mazhab Hukum Sosiological Jurisprudence Terhadap Perkembangan Pembangunan Hukum Di Indonesia Pada Masa Orde Baru.”
} 
that they do not have a strong political position to impose their aspirations and interests to be accommodated by the DPR into laws or other government legal products. ${ }^{27}$

\section{Formalization of Islamic Law as Social Engineering in Indonesia}

The sentences of Islamic law are not found in the sources of Islamic teachings and classical Islamic literature. Most mentioned are the terms of Islamic sharia, sharia law, fiqh, and sharia. ${ }^{28}$ The term Islamic law is often mentioned by orientalists with the sentence of Islamic Law, which literally translated into Indonesian is hukum Islam or Islamic law. ${ }^{29}$ When it is associated with the terms shari'a and fiqh, then Islamic law covers both terms because Islamic law is essentially a law based on Allah's revelation. ${ }^{30}$

According to Hasbi Ash-Shiddieqy, Islamic law is the manifestation of fiqh alIslam and syari'ah al-Islam. Based on the terminology of Islamic law, according to Hasbi, there is a distinction between figh al-Islam and syari'ah al-Islam. Hasbi argued that Islamic law is a collection of the efforts of the fuqaha in implementing the syari'ah al-Islam according to the needs of the community. ${ }^{31}$ Thus, syari'ah al-Islam is the domain of Allah's revelation, while fiqh al-Islam is a product of reason which is a form of revelation implementation from the two main sources of Islamic law, namely the Qur'an and Hadith that based on the benefit of human life. Aspects of the syari'ah usually regulate principled human behavior, so the benefits lie in the specific and general rules that have been outlined by the syari'ah. Therefore, the legal provisions are usually static and rigid. On the other hand, in fiqh, the dimensions of benefit are regulated in general, and the application of which cannot be separated from the development of the dynamics of human social and cultural life itself. Therefore, the law in the fiqh, in general, will always change.

Islamic law is a norm that always lives following the dynamics of society, having a constant movement and always develop. Thus, Islamic law will always grow and develop itself is the nature of Islamic law, having a character and specific characteristics, namely intact, harmonious and dynamic. Islamic law always moves in

\footnotetext{
${ }^{27}$ Sibuea and Haryono.

28 Amir Syarifuddin, Pembaharuan Pemikiran Dalam Hukum Islam (Padang: Angkasa Raya, 1993).

29 Ahmad Hasan Ridwan and Irfan Safruddin, Dasar-Dasar Epistemologi Islam (Bandung: Pustaka Setia, 2011).

${ }^{30}$ Syarifuddin, Pembaharuan Pemikiran Dalam Hukum Islam.

${ }^{31}$ M. Hasbi Ash-Shiddieqy, Filsafat Hukum Islam (Jakarta: Bulan Bintang, 1975).

https://e-journal.iain-palangkaraya.ac.id/index.php/maslahah/index
} 
the circle of the benefit of human life. ${ }^{32}$ Through this explanation, Islamic law has an inseparable functional relationship with society as Islamic law regulates human behavior and actions as its object (mahkum fih).

A challenge for Islamic law to be responsive is the rapid dynamics of the development of human life, including social, cultural, political, legal, and others. The changes in human life have positive values for human life, but not a few also bring negative values to human life, even though the purpose of Islamic law is to maintain human life which can simply be formulated to maintain benefit and eliminate the harm or disadvantages to life. For this reason, how does Islamic law respond to it? while the texts as sources of Islamic law are quantitatively limited, as well as fiqh products in fiqh literature which are the result of past intellectual property riches by socio-cultural settings of the people at that time. This is where the role of ijtihäd with the function of actualization and re-actualization finds could work.

Concerning society, Islamic law comes in two forms. First, legalizing the norms that are impersonally formed by the community. And, intervening in these norms, including eradicating a tradition in society that is not following the Sharia such as the prohibition of khamr (liquor/wine), and guiding people to behave following the Sharia. ${ }^{33}$ In this context, Islamic law, like any other law, can be used as a means of social engineering. In line with the principles of Islamic teachings which are also one of the principles of Islamic law, are the principle of Enjoining what is right (amr al-ma'ruf) and forbidding what is wrong (nahy al-munkar). According to A. Halil Thahir, the command to goodness (amr al-ma'ruf) is a form of social engineering of Islamic law, namely realizing a better and dignified human life as it is natural with methods and approaches that can be accepted by common sense, traditions, and culture of society. Whereas the meaning of nahy al-Munkar of Islamic law means social control, ${ }^{34}$ which plays as a ruler of human life so that life depend on benefits and avoids muḍarat (harm or disadvantages). ${ }^{35}$

${ }^{32}$ Ridwan and Safruddin, Dasar-Dasar Epistemologi Islam.

33 This case here is like Islam which regulates the practice of polygamy which has become a culture of Arab people for a long time without paying attention to women. Islam regulates polygamy by bringing moral ideas into it.

34 A. Halil Thahir, Ijtihad Maqashid: Rekonstruksi Hukum Islam Berbasis Interkoneksitas Maslahah (Yogyakarta: LKiS Pelangi Aksara, 2015).

${ }^{35}$ Izomiddin, Pemikiran Dan Filsafat Hukum Islam (Jakarta: Prenamedia Group, 2018). 
Discussing social engineering, Islamic law serves as a means of change in society and leads to real social changes in society. This task is manifested in the effort of strengthening the habit patterns in society, leading them to the desired goals, eliminating unnecessary habits, and creating new habit patterns. ${ }^{36}$

In many ways, when Islamic law becomes part of a Muslim's religion, it will often be faced with traditions that already exist and are rooted in the culture of society. Then, there will occur a dialectic between the practice of Islamic law which is part of Islam, and the cultural practices of the community. With Islam, it is not true that all of already a continuous habit becomes forbidden. When looking at the fiqh literature, often stated that Islam is very appreciative either to the traditions or habits of good society and in line with the benefit of human life itself. We all can see a legal rule ${ }^{37}$ that reads العادة is the reason for a good community tradition also a part of Islamic law itself, especially in muamalah matters. But, a tradition must meet several criteria to become a law. First, a tradition must not conflict with a strict text. Second, a behavior that becomes a custom or tradition must continue to apply and develop in the middle of the community. Third, tradition is common because common laws cannot be determined by a specific tradition. ${ }^{38}$

An example is, harta parpantangan (prenuptial property) which departs from the culture of the Banjarese community. Harta parpantangan is defined as joint property in marriage, or Javanese terms, called harta gono gini (has the same as meaning as harta parpantangan). As in Banjarese culture, a wife is usually considered to help her husband in married life, both working outside the home and in sharing tasks, namely, the husband works outside the home and the wife works as a housewife. Activities during the status of husband and wife are considered as a form of cooperation. Therefore, the acquired property while they are in the same household (husband and wife) are approved as joint property. Appreciating the wife's role in the household as a

\footnotetext{
${ }^{36}$ Soerjono Soekanto, Pemikiran Sosiologi Terhadap Hukum (Jakarta: Bina Aksara, 1998).

${ }^{37}$ The rule in Islamic law becomes a foundation in establishing a law and many cases of law in which refer to the rules. From this foundation of rule, arise a fiqh rule. This shows that scholars, in the past time, have a big concern for the tradition and custom that life and develop in the middle of the community. The majority of scholars define the word "al-Adat" and 'Urf' as different, but, the meaning and definition of both words are referred to a tradition and habit that is continuous life and well-known by the community itself. DAR NELA PUTRI, "Konsep Urf Sebagai Sumber Hukum Dalam Islam," ElMashlahah 10, no. 2 (2020): 14-25, https://doi.org/10.23971/maslahah.v10i2.1911.

${ }^{38}$ Ash-Shiddieqy, Filsafat Hukum Islam.
} 
form of cooperation with the husband is a bilateral community culture. This status is different from the Arab culture in general, which is dominantly patriarchal, considers that the husband's property who works outside the home is the husband's property, not the wife's property. ${ }^{39}$ The concept of harta parpantangan ${ }^{40}$ is the result of ijtihad conducted by Sheikh Arsyad Al-Banjari concerning inheritance provision. It is a manifestation of the dialectic of Islamic law which respects the role of husband and wife in the household with community customs that have long-lived as a living law system in society. These practices gain legitimacy in Islamic law, and in the end, become an integral part of the application of Islamic law itself, especially in Indonesia.

Islamic law in Indonesia, theoretically and factually, is one of the laws that exist and grow in the middle of society, which is predominantly Muslim. Denying the existence of Islamic law in Indonesia is the same as denying the existence of Muslims themselves as an integral part of the Indonesian people. Therefore, Islamic law is recognized as one of the sources of national law which have been expressly stated in the 1999 GBHN in the reform era. ${ }^{41}$ This means, in making legislation, Islamic law takes part as a legal material for the product of national legislation.

Islamic law may be understood from two views, science and a product of science. Islamic law, in the context of science, is the scientific characteristics of the Islamic law that are produced through the accumulation of knowledge that is structured through certain principles. The knowledge is centered in a unified system and has certain methods. ${ }^{42}$ As a product of science, Islamic law has four kinds of products, namely figh books, the fatwa of ulama, court decisions, and law. ${ }^{43}$ In the context of Indonesia which applies juridical positivism, ${ }^{44}$ to realize the Islamic law as a tool of social engineering

\footnotetext{
${ }^{39}$ Ahmadi Hasan, Adat Badamai (Banjarmasin: Antasari Press, 2007).

${ }^{40}$ M. Fahmi Al-Amruzi, Harta Kekayaan Perkawinan Studi Komparatif Fiqh, KHI, Hukum Adat Dan KUHPerdata (Yogyakarta: Aswaja Pressindo, 2013).

41 A. Qadri Azizi, Eklektisme Hukum Nasional: Kompetisi Antara Hukum Islam Dan Hukum Umum (Yogyakarta: Gema Media, 2002).

${ }^{42}$ Yusdani, Menuju Hukum Keluarga Progresif (Jakarta: Kaukaba, 2015).

43 Yusdani.

44 Juridical positivism is a school in legal philosophy that adheres to the notion, that only what is approved to be reality can be accepted as truth and right. Positivism as a philosophical school emerged in the 19th century with its figures including Auguste Comte (1779-1854 AD) and Herbert Spencer (18201903). Meanwhile, Juridical Positivism was pioneered by the legal school of Humanism, whose the figure is Jean Bodin with his theory of the sovereignty of the King. Theo Hujbers, Filsafat Hukum Dalam Lintasan Sejarah (Yogyakarta: Kanisius, 1982).
} 
must make the Islamic law a product of official legislation. ${ }^{45}$ Without entering into the positive realm, Islamic law will only become a product of fiqh which is ideological and teaching for its followers. ${ }^{46}$

By this discussion, the discourse on the formalization of Islamic law in Indonesia is inevitable because the goal is to make Islamic law an official (positive) law and applicable in Indonesia. This discussion has been going on for a long time, from the colonial era until today. In a relationship between Islamic law and the state, at least, three paradigms have developed related to the formalization of Islamic law. First, a unified paradigm. This paradigm views the state with two functions, religious and political institution. As the impact, the head of state is the holder of religious and political power. The government is based on the sovereignty of God. Thus, the laws that are implemented in the state system are the laws of God (sharia).

From an integral perspective, the enforcement and application of Islamic law as positive state law is a necessity. ${ }^{47}$ The second, the symbiotic paradigm. This paradigm views religion and state as having a symbiotic relationship. Religion needs the state because, through the state authority, religion can always develop and live. Also, the state needs religion due to the process of developing the state needs the guidance of spiritual ethics and morals.

This paradigm comes from al-Mawardi's theory, that state leadership is an instrument to continue the prophetic mission in maintaining religion and regulating world life. In this case, maintaining the religion and the state are two different types of activities but have a prophetic mission relationship. In this concept, Islamic law

45 In Indonesia, all forms of law will be effective when they have been promulgated by the authorities (government of the Republic of Indonesia). On the other hand, no matter how good and complete the existing legal regulations in Indonesia are, they will not apply if they have not been officially promulgated by the authorities. Mujar Ibnu Syarif, Ide Taqnin Ibn Al-Muqaffa Dan Relevansinya Dengan Penerapan Syariat Islam Di Indonesia (Jakarta: Renaisan dan Formasi, 2005).

${ }^{46}$ In the history of Islamic legal thought, making the positive of Islamic law into legislation is known as taqnin, which was first coined by Ibn al-Muqaffa in a letter that sent to Caliph Ja'far al-Mansur of the Abbasid dynasty. The letter is called Risalah al-Shabah. In the developing years of this thought, the scholars were divided into two groups, first the group that allowed taqnin al-Ahkam with various arguments. And second, the group of scholars that do not justify taqnin al-Ahkam with various arguments. The difference is the issue of the position of judges who must conduct ijtihad and the reality of diversity in fiqh as a product of ijtihad. Ujang Ruhyat Syamsoni, "Taqnin Al-Ahkam (Legislasi Hukum Islam Ke Dalam Hukum Nasional)," Nur El-Islam 2, no. 2 (2015): 168-93, https://ejurnal.iaiyasnibungo.ac.id/index.php/nurelislam/article/view/28.

${ }^{47}$ Rahmatunnair Rahmatunnair, "Paradigma Formalisasi Hukum Islam Di Indonesia," AHKAM : Jurnal Ilmu Syariah 12, no. 1 (2012): 99-108, https://doi.org/10.15408/ajis.v12i1.984. 
occupies a central position as a source of legitimacy for political realities. On the other hand, the state has a major role in enforcing Islamic law correctly and appropriately. Third, the secularistic paradigm. This paradigm views the relationship between religion and the state as diametrically dichotomized. This paradigm rejects state law based on Islamic law, even rejects Islamic determination towards certain forms of state. Thus, Islamic law cannot simply be applied and enforced in a particular country. Islamic law cannot be used as positive state law unless it has been accepted by the state as national law. ${ }^{48}$

Rahmatunnair argues that the formalization of Islamic law should take the form of transformation and internalization of Islamic legal values into the national legal system. In this case, Islamic law is not only seen as a static norm that prioritizes certainty and order but is also a norm that must be able to dynamically think and manipulate people's political behavior in realizing their ideals. ${ }^{49}$ Here, there are two reasons, external and internal reasons. The external reason is the state constitution which provides opportunities for the application of Islamic law for Indonesian Muslims, as reflected in Pancasila (Five Pillars) and the 1945 Constitution of the Republic of Indonesia. While the internal reason is, Islamic law itself which has legal principles, can be applied and accepted by the community and provide justice. In addition, in terms of the means that provide opportunities for the formalizing Islamic law, no less important is the maqașid al-syari'ah or the goal of Islamic law which is aimed towards achieving happiness (benefits) and avoiding all forms of arbitrariness (harm). ${ }^{50}$

Based on the previous description, Islamic law as social engineering is an attempt to re-establish justice by applying Islamic law in regulations or legislation in the state. In addition, Islamic law must be able to adapt by continuing to make various approaches with other sciences to produce a social reflection. In this position, it makes Islamic law ease in accelerating the society, which is hope, as an effort to obtain justice through social engineering.

To achieve justice, there are two important considerations. The first is the source. And, second is the formulation of justice itself. The sources of the Islamic law that

\footnotetext{
${ }^{48}$ Rahmatunnair.

${ }^{49}$ Rahmatunnair.

${ }^{50}$ Rahmatunnair.
} 
come from God's revelation, must answer the social challenges which in general always move dynamically following the development of the social culture of society. Here is the urgency of the role of the fuqaha, ulama, and other Muslim scholars to implement and develop Islamic law. Therefore, according to Fathurrahman Azhari, Islamic law, as part of the product of classical ulama thought in the context of social engineering, is understood by not being absolute or accepting the change. So, the things that are no longer in accordance with contemporary times need to be reviewed. ${ }^{51}$ In the aspect of the formulation of justice, Islamic law must be formulated in law or guidance in seeking justice. The reason is to achieve a universal law by achieving justice for humans and justice in the sight of God. ${ }^{52}$

A law of a realization of positive of Islamic $\operatorname{law}^{53}$ and has a function as a means of social engineering is Law Number 1 of 1974 concerning Marriage. Historically, this law was born from a hope from the government to make an Indonesian family with a national personality and a modern perspective. In addition, the Marriage Law is expected to regulate the creation of a future Indonesian family that is compatible with modern industrial society. ${ }^{54}$

One of the articles that show the social reconstruction efforts in the Act is related to marriage registration. In the explanation of the marriage law in the section on the principles of marriage in Indonesia, it states that the registration of each marriage is the same as important events in a person's life, for example, births or deaths which are stated in certificates, an official certificate which is also contained in the marriage registration. This shows that the state with its power is trying to perform social engineering by adding marriage requirements beyond the conditions in the fiqh book. In this case, the state conducts a marriage registration as a form of protection for all its

51 Fathurrahman Azhari, "Dinamika Perubahan Sosial Dan Hukum Islam," Al-Tahrir: Jurnal Pemikiran Islam 16, no. 1 (June 24, 2016): 197-221, https://doi.org/10.21154/al-tahrir.v16i1.322.

52 Abdul Ghofur Anshori, Filsafat Hukum, Sejarah Aliran Dan Pemikiran (Yogyakarta: Gajah Mada University Press, 2005).

${ }^{53}$ The figure who clearly states that act No 1 of 1974 is a product of Ijtihad is Prof. Dr. Hazairin, S.H. in a discussion section about the relationship between Islamic Marriage law and this particular marriage law. There are two arguments. The first argument is stated by Hazairin. The second argument is argued by Prof. Dr. J. Prins that has contradicted with the argument of Prof. Dr. Hazairin, S.H. But, M. Tahir Azhary approved the arguments that act No 1 of 1974 on marriage law is a product of Ijtihad. Danu Aris Setiyanto, "Hukum Islam Sebagai Rekayasa Sosial Dan Implikasinya Dalam Undang-Undang Perkawinan Di Indonesia," Ijtihad: Jurnal Wacana Hukum Islam Dan Kemanusiaan 17, no. 2 (2018): 175, https://doi.org/10.18326/ijtihad.v17i2.175-189.

${ }^{54}$ Setiyanto. 
citizens in guaranteeing the rights and obligations of each family member. ${ }^{55}$ And, the marriage law for Muslims that has been applied following the fiqh, since hundreds of years ago until now, does not contain the condition of marriage registration. For every Muslim, as long as the marriage is following the pillars and conditions outlined in the books of fiqh, then, the marriage is valid. Article 2 paragraph 1 of the Law accommodates the things that have been implemented by Indonesian Muslims. However, article 2 paragraph 2 which requires the registration of marriages shows that there is an effort by the government to add administrative requirements as a form of legal certainty and protection for its citizens.

Islamic law as a means of social reconstruction can also enter the public law, namely by making it as a review by the government to explore the sources of power to be used by using Islamic law as a mechanism. Corruption in Indonesia is very severe, and, it has become a culture. But, the punishment punished for the corruptors in Indonesia is still very light. The government, as a policymaker as well as a supervisory and regulatory apparatus for a legal product, must make a policy or legislation to be social engineering for all people in Indonesia.

Efforts need to consider by the government. For example, the law needs to consider the sources of law that live in society, such as Islamic law. It must be realized, that corruption is a form of extraordinary crime, just like terrorism and drugs. In Islamic law, criminal acts of corruption can be imposed with the type of ta'zir punishment with the heaviest punishment of a death sentence to a light one, such as imprisonment, according to the severity of the act and the impact of corruption committed. ${ }^{56}$ The views of Muslim scholars and intellectuals can be applied in the laws and regulations in Indonesia so that the giving of sanctions for criminal acts of corruption for those who commit criminal acts of corruption repeatedly (recidivists) can be sentenced to a maximum penalty of death. Also, the crime of corporation corruption (jointly) for those who are proven to have committed an evil conspiracy by jointly causing losses to the

55 Setiyanto.

${ }^{56}$ Bambang Widjoyanto, Abdul Malik Gismar, and Laode M. Syarif, Koruptor Itu Kafir: Telaah Fiqh Konsepsi Dalam Muhammadiyah Dan Nahdlatul Ulama (Bandung: Mizan, n.d.). 
State, could be given severe punishment, even the death penalty following the Qur'an, al-hadith, 'Ijma, and fatwa from fiqhiyah scholars. ${ }^{57}$

\section{Conclusion}

Islamic law in Indonesia is part of the living law in the Indonesian Muslim community. Moreover, the existence of it is recognized as one of the sources of national law, besides Western law and customary law. This opens the opportunity to make Islamic law act as a means of social reconstruction, namely to create a better social condition. To make Islamic law a means of social reconstruction, the formalization of Islamic law is inevitable. However, the formalization must be in the form of transformation and internalization of the values contained in Islamic law into the national law. In this case, Islamic law is not a static norm but must be understood as a norm that can dynamize thought and engineer the people's political behavior in realizing their ideals.

\section{BIBLIOGRAPHY}

Agustian, Tomi. "Formalisasi Hukum Islam Kedalam Tata Hukum Indonesia." ELGhiroh 16, no. 01 (2019): 15-36. https://doi.org/10.37092/el-ghiroh.v16i01.72.

Ahmad, Sabarudin, Novita Anggraeni, and Andrian Kukuh Pambudi. “A. Djazuli's Thinking Regarding Hifzu Al-Ummah: Dismissing the Entangled Bureaucracy to Commemorate the Era of Society 5.0." Journal de Jure 12, no. 1 (2020): 86-101. https://doi.org/10.18860/j-fsh.v12i1.8700.

Al-Amruzi, M. Fahmi. Harta Kekayaan Perkawinan Studi Komparatif Fiqh, KHI, Hukum Adat Dan KUHPerdata. Yogyakarta: Aswaja Pressindo, 2013.

Ali, Ahmad. Menguak Tabir Hukum (Suatu Kajian Sosiologis Dan Filosofis). Jakarta: Toko Gunung Agung, 2002.

Anshori, Abdul Ghofur. Filsafat Hukum, Sejarah Aliran Dan Pemikiran. Yogyakarta: Gajah Mada University Press, 2005.

Ash-Shiddieqy, M. Hasbi. Filsafat Hukum Islam. Jakarta: Bulan Bintang, 1975.

Atmajaya, A.P. Edi. "Hukum Sebagai Sarana Rekayasa Sosial.” Opini Radar Lampung, 2012. https://issuu.com/ayep2/docs/300512/6.

Azhari, Fathurrahman. "Dinamika Perubahan Sosial Dan Hukum Islam." Al-Tahrir: Jurnal Pemikiran Islam 16, no. 1 (June 24, 2016): 197-221. https://doi.org/10.21154/al-tahrir.v16i1.322.

Azizi, A. Qadri. Eklektisme Hukum Nasional: Kompetisi Antara Hukum Islam Dan

\footnotetext{
${ }^{57}$ Martha Safira, "Law as a Tool of Social Engineering Dalam Penanganan Tindak Pidana Korupsi Di Indonesia Ditinjau Dari Hukum Islam Dan Perundang-Undangan Di Indonesia," Kodifikasia 11, no. 1 (2017): 118-33, https://doi.org/10.2991/icsse-17.2018.28.
} 
Hukum Umum. Yogyakarta: Gema Media, 2002.

Darmodiharjo, Dardi. Pokok-Pokok Filsafat Hukum: Apa Dan Bagaimana Filsafat Hukum Indonesia. Jakarta: Gramedia Pustaka Utama, 1996.

Diab, Ashadi L. "Peranan Hukum Sebagai Social Control, Social Engineering Dan Social Welfare." Al-'Adl 7, no. 2 (2014): 53-66. https://ejournal.iainkendari.ac.id/al-adl/article/view/219.

Halim, Fatimah. "Hukum Dan Perubahan Sosial." Al-Daulah: Jurnal Hukum Pidana \& Ketatanegaraan 4, no. 1 (2015): 107-15. http://journal.uinalauddin.ac.id/index.php/al_daulah/article/view/1492.

Hasan, Ahmadi. Adat Badamai. Banjarmasin: Antasari Press, 2007.

Hujbers, Theo. Filsafat Hukum Dalam Lintasan Sejarah. Yogyakarta: Kanisius, 1982.

Izomiddin. Pemikiran Dan Filsafat Hukum Islam. Jakarta: Prenamedia Group, 2018.

Kosasih, Johannes Ibrahim, and Yohanes Hermanto Sirait. "Konsepsi Law As A Tool Of SOcial Engineering Sebagai Upaya Manajemen Hukum Dalam Menciptakan Kepastian Hukum." In Konferensi Nasional Optimalisasi COmminity Well-Being Dalam Perspektif Multidisipliner, 45-46. Bandung: Fakultas Psikologi Universitas Kristen Maranatha, 2015.

Kurniawan. "Dinamika Formalisasi Syariat Islam Di Indonesia." Kanun: Jurnal Ilmu Hukum 14, no. 3 (2017): 423-47. https://doi.org/10.24815/kanun.v14i3.6223.

Kusumaatmadja, Mochtar. Konsep-Konsep Hukum Dalam Pembangunan. Bandung: Alumni, 2002.

Lathif, Nazaruddin. "Teori Hukum Sebagai Sarana Alat Untuk Memperbaharui Atau Merekayasa Masyarakat." Palar | Pakuan Law Review 3, no. 1 (2017): 73-94. https://doi.org/10.33751/palar.v3i1.402.

Najib, Muhammad Ainun. "Politik Hukum Formalisasi Syariat Islam Di Indonesia." IN RIGHT: Jurnal Agama Dan Hak Azazi Manusia 6, no. 2 (2017): 156-74. http://ejournal.uin-suka.ac.id/syariah/inright/article/view/1449.

PUTRI, DAR NELA. "Konsep Urf Sebagai Sumber Hukum Dalam Islam." El$\begin{array}{lllll}\text { Mashlahah } & 10, & \text { no. } & 2 & \text { (2020): }\end{array}$ https://doi.org/10.23971/maslahah.v10i2.1911.

Raharjo, Satjipto. Ilmu Hukum. Bandung: Alumni, 1986.

Rahmatunnair, Rahmatunnair. "Paradigma Formalisasi Hukum Islam Di Indonesia." AHKAM: Jurnal Ilmu Syariah 12, no. 1 (2012): 99-108. https://doi.org/10.15408/ajis.v12i1.984.

Rasyidi, Lili. Filsafat Hukum. Bandung: Remaja Rosdakarya, 1988.

Rasyidi, Lili, and Rasyidi Ira. Dasar-Dasar Filsafat Hukum. Bandung: Citra Aditya, 1990.

Ridwan, Ahmad Hasan, and Irfan Safruddin. Dasar-Dasar Epistemologi Islam. Bandung: Pustaka Setia, 2011. 
Safira, Martha. "Law as a Tool of Social Engineering Dalam Penanganan Tindak Pidana Korupsi Di Indonesia Ditinjau Dari Hukum Islam Dan Perundang-Undangan Di Indonesia." Kodifikasia 11, no. 1 (2017): 118-33. https://doi.org/10.2991/icsse17.2018.28.

Setiyanto, Danu Aris. "Hukum Islam Sebagai Rekayasa Sosial Dan Implikasinya Dalam Undang-Undang Perkawinan Di Indonesia." Ijtihad: Jurnal Wacana Hukum Islam $\begin{array}{llllll}\text { Dan Kemanusiaan } & 175 .\end{array}$ https://doi.org/10.18326/ijtihad.v17i2.175-189.

Sibuea, Hotma P, and Waty Suwarty Haryono. "Pengaruh Mazhab Hukum Sosiological Jurisprudence Terhadap Perkembangan Pembangunan Hukum Di Indonesia Pada Masa Orde Baru." Jurnal Filsafat Hukum 1, no. 1 (2015): 103-11. http://journal.uta45jakarta.ac.id/index.php/JFH/article/view/1480.

Soekanto, Soerjono. Pemikiran Sosiologi Terhadap Hukum. Jakarta: Bina Aksara, 1998.

Syamsoni, Ujang Ruhyat. "Taqnin Al-Ahkam (Legislasi Hukum Islam Ke Dalam Hukum Nasional)." Nur El-Islam 2, no. 2 (2015): 168-93. https://ejurnal.iaiyasnibungo.ac.id/index.php/nurelislam/article/view/28.

Syarif, Mujar Ibnu. Ide Taqnin Ibn Al-Muqaffa Dan Relevansinya Dengan Penerapan Syariat Islam Di Indonesia. Jakarta: Renaisan dan Formasi, 2005.

Syarifuddin, Amir. Pembaharuan Pemikiran Dalam Hukum Islam. Padang: Angkasa Raya, 1993.

Thahir, A. Halil. Ijtihad Maqashid: Rekonstruksi Hukum Islam Berbasis Interkoneksitas Maslahah. Yogyakarta: LKiS Pelangi Aksara, 2015.

Widjoyanto, Bambang, Abdul Malik Gismar, and Laode M. Syarif. Koruptor Itu Kafir: Telaah Fiqh Konsepsi Dalam Muhammadiyah Dan Nahdlatul Ulama. Bandung: Mizan, n.d.

Wigisoebroto, Soetandyo. Dari Hukum Kolonial Ke Hukum Nasional: Dinamika Sosial Politik Dan Perkembangan Hukum Di Indonesia. Jakarta: Rajawali Press, 1994.

Yusdani. Menuju Hukum Keluarga Progresif. Jakarta: Kaukaba, 2015. 